\title{
Synthesis and Characterization of 2,3-Diaminomaleonitrile Derivatives by One-Pot Schiff Base Reaction and Their Application in Dye Synthesized Solar Cells
}

\author{
Saifaldeen Muwafag Abdalhadi ${ }^{1^{*}}$, Asmaa Yahya Al-Baitai ${ }^{2}$, and Hazim Abdulrazzaq Al-Zubaidi ${ }^{3}$ \\ ${ }^{1}$ Department of Remote Sensing, College of Remote Sensing and Geophysics, Al-Karkh University of Science, Baghdad, Iraq \\ ${ }^{2}$ Department of Chemistry, College of Science, Al-Nahrain University, Baghdad, Iraq \\ ${ }^{3}$ Department of Biomedical Science, College of Science, Al-Karkh University of Science, Baghdad, Iraq
}

${ }^{*}$ Corresponding author:

tel: $+964-7702777191$

email:dr.saifaldeen80@gmail.com

Received: July 3, 2020

Accepted: October 5, 2020

DOI: $10.22146 /$ ijc. 57535

\begin{abstract}
In a one-pot reaction, three new 2,3-diaminomaleonitrile (DAMN) derivative dyes were prepared by simple Schiff base reaction. The compounds were designed as a sensitizer in dye synthesizes solar cells (DSSCs). Many conditions have been used to provide the methodology to get the best yield. The prepared dyes were characterized by melting point, elemental microanalysis, mass spectroscopy, FT-IR, ${ }^{1} H-N M R$, and UV-Vis spectroscopy. A computational study was carried out to support our results. The DSSC data was shown the best performance for SA3 dye with $0.38 \%$ efficiency at AM 1.5 then SA2 with $0.22 \%$ and the last dye is SA1 with 0.09\%, compared to control cell (N719) $5.4 \%$.
\end{abstract}

Keywords: one-pot reaction; 2,3-diaminomaleonitrile; Schiff base; DSSCs

\section{- INTRODUCTION}

Photovoltaic technology is one of the most important techniques which involved generating clean energy from free sunlight [1-3]. During the last two decades, dye-sensitized solar cells (DSSCs) arguably offer a promising photovoltaic technology due to their cheap and simple fabrication process and methods [4-8]. DSSCs have other specific advantages represented by the possible flexibility, chemical versatility, colorful appearances, and a vast synthetic way to different organic and organometallic molecular structures [9-13]. DSSCs consists of different parts: (1) Transparent conductive glass sheet electrode which is coated with fluorine-doped tin oxide (FTO) or indium tin oxide (ITO); (2) Semiconductor layer coated on the FTO glass sheet such as $\mathrm{TiO}_{2}$ or $\mathrm{ZnO}_{2}$ which is used as a working electrode; (3) Organic or organometallic dye which is design as a donor, $\pi$-bridge and acceptor to improve the transferring the excited electron from the donor to acceptor part; (4) Electrolyte solution which carries the electron from counter electrode to the dye and usually used an iodide/triiodide as a redox electrolyte in DSSC; (5) A counter electrode which is used to close the circuit of the solar cells from glass sheet coated with a metal such as Platinum [1-2].

In 1991, O'Regan and co-workers developed the first effective DSSCs, with a power conversion efficiency (PCE) of 7\% under the illumination of AM 1.5 [14]. Ten years later, Nazeeruddin and co-workers employed nano-powder $\left(\mathrm{TiO}_{2}\right)$ as a semiconductor electrode, and the efficiency of DSSCs was reported to be $11.4 \%$ [15]. A wide range of organic dyes with the donor and acceptor system has been designed for DSSCs [16-18].

The free-metal organic dyes have many advantages over organometallic dyes such as cost efficiency, high extinction coefficient, and environmentally friendly [1921]. The best organic dyes in DSSC are based on the chromophore as a donor part such as dimethylaniline [22-24] and coumarins derivatives [25-27]. Also, $\pi$ bridge played significant roles in dyes design. For instance, Michele C. and co-workers reported the synthesis of two porphyrin dyes with two different $\pi$ bridge spacers. The two dyes (PorF and PorT) contain the furan and thiophene group, respectively as a $\pi$ conjugation linker between the same donor and acceptor parts. A significant difference in the efficiencies $(\eta)$ has been noticed, which based furan dye $(\eta=4.5 \%)$ 
being more efficient than thiophene dye $(\eta=3.6 \%)$ [28]. Gao and co-workers published their work used four different dyes with the elongation of a $\pi$-conjugated bridge by using 3,4-ethylenedioxythiophene (EDOT) as a $\pi$ bridge spacer. Unexpectedly, the longest $\pi$-bridge dye showed the lowest efficiency [29].

2,3-Diaminomaleonitrile (DAMN) has been used to prepare a wide range of organic compounds due to the significant applications of DAMN derivatives to synthesis symmetrical and unsymmetrical dyes with different physical and chemical properties [30-34]. There are few studies available about the DAMN derivative as a dye in DSSCs. This paper describes the synthesis of three unsymmetrical push-pull systems by using the Schiff base reaction in a one-pot process. The three dyes are based in DAMN as a $\pi$ conjugation linker, benzene derivative as a donor part, and benzoic acid as an acceptor part, and these dyes are used as dyes in DSSCs. Different types of conditions were used in these reactions to get the best yield for the final compound. Finally, the advantages of the one-pot reaction protocol were represented by a significant reduction in synthesis time and purification cost [35-37].

\section{- EXPERIMENTAL SECTION}

\section{Materials}

All starting materials and solvents were purchased from Alfa Aesar, TCI, and Sigma-Aldrich and used as received without any purification. All reactions were run under a nitrogen atmosphere. Silica gel of column chromatography was used from Merck (40-63 $\mu \mathrm{m} 60 \AA$ ).

\section{Instrumentation}

${ }^{1} \mathrm{H}-\mathrm{NMR}$ and ${ }^{13} \mathrm{C}-\mathrm{NMR}$ spectra were recorded with a Bruker Avance-DPX-250/400 spectrometer operating 400/100 MHz respectively, using tetramethylsilane (TMS) as an internal standard and DMSO- $\mathrm{d}^{6}$ or $\mathrm{CDCl}_{3}$ as the solvent. UV-Vis absorption spectra were recorded on a Shimadzu UV-3600 UV-Vis-NIR spectrometer. Mass spectra were obtained on a Bruker MicroTOF QII. Elemental analyses $(\mathrm{C}, \mathrm{H}$, and $\mathrm{N})$ were tested on a Perkin Elmer $240 \mathrm{C}$ analyzer. Computational studies were performed using Gaussian 09 software. The molecular structure was initially optimized by semi-empirical (AM1) and then reoptimized by Density Functional Theory (DFT).

\section{Procedure}

\section{Preparation of dyes}

The three Schiff base dyes were synthesized by the same procedure, Fig. 1, 1.0 mmol of one of the aldehyde derivatives ( $(0.11 \mathrm{~g}, 1.0 \mathrm{mmol})$ benzaldehyde (1), (0.15 g, $1.0 \mathrm{mmol}$ ) 4-(dimethyl-amino)benzaldehyde (2), $(0.17 \mathrm{~g}, 1.0 \mathrm{mmol}) 3,5$-dimethoxybenzaldehyde (3)) and $(0.16 \mathrm{~g}, 1.5 \mathrm{mmol})$ of DAMN (4) were introduced to 2neck round-bottom flask under a nitrogen atmosphere. Absolute ethanol $(50 \mathrm{~mL})$ was added to the mixture with two drops of glacial acetic acid as a catalyst. The mixture was allowed to stir for $5 \mathrm{~h}$ at $80^{\circ} \mathrm{C}$. After this time $0.3 \mathrm{~g}$, $2.0 \mathrm{mmol}$ of 4 -formylbenzoic acid (5) was dissolved in $10 \mathrm{~mL}$ of absolute ethanol and added via a syringe to the mixture, and left to stir at $80{ }^{\circ} \mathrm{C}$ for $15 \mathrm{~h}$. The mixture was allowed to cool at room temperature and the crude product was left to precipitate overnight in the mother solution. Then, the precipitate was filtered and washed with cold methanol. The crude product was purified by column chromatography $\left(\mathrm{SiO}_{2}, \mathrm{DCM}\right.$ :acetone; $\left.9: 1\right)$ to give a compound as a powder.

\section{Preparation and testing DSSCS}

ITO conductive glass sheets were cleaned by using a detergent solution in an ultrasonic bath for $10 \mathrm{~min}$, then rinsed with distilled water and ethanol. $\mathrm{TiO}_{2}$ was prepared by adding $15 \mathrm{~mL}$ of ethanol to the $3.0 \mathrm{~g}$ of $\mathrm{TiO}_{2}$ nanopowder (10-25 nm, US Research Nanomaterial, Inc, USA) and then added $2.5 \mathrm{~mL}$ of Triton X-100. The mixture was stirred using a small magnetic bar for $45 \mathrm{~min}$ to form $\mathrm{TiO}_{2}$ paste. The $\mathrm{TiO}_{2}$ paste was dropped to the top of the ITO glass sheet by using an eye pipette and then deposited by doctor blade technique to form a $\mathrm{TiO}_{2}$ thin layer $\left(0.5 \mathrm{~cm}^{2}\right.$ area). The glass sheet with the $\mathrm{TiO}_{2}$ layer was heated at $70{ }^{\circ} \mathrm{C}$ for $30 \mathrm{~min}$ then sintered at $400{ }^{\circ} \mathrm{C}$ for $45 \mathrm{~min}$. After cooling, the deposit $\mathrm{TiO}_{2}$ was immersed in the dye solution $\left(10^{-3} \mathrm{M}\right)$ for $5 \mathrm{~h}$. The counter electrode was made by sketching a pencil (graphite pencil) on the surface of another conductive glass (ITO). The $\mathrm{TiO}_{2}$ thin layer with dye and counter 
electrode were assembled to form a DSSC by sandwiching with a redox electrolyte solution $\left(\mathrm{I}^{-} / \mathrm{I}_{3}^{-}\right)$.

For DSSCs testing, a solar simulator with a xenon light source (450 W, Osram XBO 450) and filter (Schott 113) was used to test fabricated solar cells. The power of the solar simulator was controlled to the standard test of the DSSCs AM 1.5 by using Si photodiode as a reference and color-matched filter (KG-3, Schott) which was used to reduce the mismatch in the wavelength $(350-750 \mathrm{~nm})$ between AM 1.5 and simulated light to less than 5\%. The setting time between voltage and current density of the $J$ $V$ characterization of the solar cells was fixed with a digital source meter (Keithley model 2400) to $80 \mathrm{~ms}$.

\section{- RESULTS AND DISCUSSION}

\section{Synthesis of Dyes}

\section{Dye characterization}

4-((E)-(((E)-2-((E)-benzylideneamino)-1,2-dicyanovinyl) imino)methyl) benzoic acid (SA1). Yield 36\%; mp. 211-213 ${ }^{\circ} \mathrm{C}$; FT-IR, $\mathrm{cm}^{-1}$ (rel. intensity), 3411 (w), 2245 (s), $1788(\mathrm{~s}), 1682(\mathrm{~s}), 1575(\mathrm{~m}), 1433,1082(\mathrm{~m}), 863(\mathrm{w})$, $776(\mathrm{w}) .{ }^{1} \mathrm{H}-\mathrm{NMR}\left(\mathrm{CDCl}_{3}, 400 \mathrm{MHz}\right): \delta 8.65(\mathrm{~s}, 1 \mathrm{H}, \mathrm{CH})$, 8.63 (s, 1H. CH), 8.09 (d, J = 9.1 Hz, 2H, Ar-H), 7.70 (d, J $=9.1 \mathrm{~Hz}, 2 \mathrm{H}, \mathrm{Ar}-\mathrm{H}), 7.60-7.39(\mathrm{~m}, 5 \mathrm{H}, \mathrm{Ar}-\mathrm{H}) \cdot{ }^{13} \mathrm{C}-\mathrm{NMR}$ $\left(\mathrm{CDCl}_{3}, 100 \mathrm{MHz}\right): \delta 168.95,147.11,136.73,136.40$, $135.66,135.49,133.06,129.61,129.60,129.50,129.05$, 127.12, 115.28. Anal. Calcd. For $\mathrm{C}_{19} \mathrm{H}_{12} \mathrm{~N}_{4} \mathrm{O}_{2}: \mathrm{C}, 69.51 ; \mathrm{H}$, 3.68; N, 17.06. Found: C, 69.53; H, 3.64; N, 17.10. EI-MS: $\mathrm{m} / \mathrm{z} 328$.

4-((E)-(((E)-1,2-dicyano-2-((E)-(4-(dimethylamino)ben zylidene)amino)vinyl)imino)methyl) benzoic acid (SA2). Yield 45\%; mp. 231-233 ${ }^{\circ} \mathrm{C}$; FT-IR, $\mathrm{cm}^{-1}$ (rel. intensity), $3432(\mathrm{w}), 2854(\mathrm{~m}), 2259$ (s), 1716 (s), 1641 (m), $1544(\mathrm{~m}), 1419$ (s), 1290 (m), 1091 (m), 860 (w), 769 (w). ${ }^{1} \mathrm{H}-\mathrm{NMR}\left(\mathrm{CDCl}_{3}, 400 \mathrm{MHz}\right): \delta 8.68(\mathrm{~s}, 1 \mathrm{H}, \mathrm{CH}), 8.44$ (s, 1H. CH), 8.06 (d, J = 9.1 Hz, 2H, Ar-H), 7.64 (d, $J=9.1$ $\mathrm{Hz}, 2 \mathrm{H}, \mathrm{Ar}-\mathrm{H}), 7.39$ (d, $J=8.4 \mathrm{~Hz}, 2 \mathrm{H}, \mathrm{Ar}-\mathrm{H}), 6.96$ (d, $J=$ $8.4 \mathrm{~Hz}, 2 \mathrm{H}, \mathrm{Ar}-\mathrm{H}), 2.93$ (s, 6H, CH). ${ }^{13} \mathrm{C}-\mathrm{NMR}$ (CDCl3, $100 \mathrm{MHz}): \delta 168.94,154.62,147.11,136.73,136.40$, $135.66,131.23,129.61,127.12,122.95,115.28,111.56$, 41.91. Anal. Calcd. For $\mathrm{C}_{23} \mathrm{H}_{23} \mathrm{~N}_{5} \mathrm{O}_{2}: \mathrm{C}, 68.81 ; \mathrm{H}, 5.77 ; \mathrm{N}$, 17.44. Found: C, 68.86; H, 5.75; N, 17.42. EI-MS: $m / z 371$.
4-((E)-(((E)-1,2-dicyano-2-((E)-(3,5-dimethoxybenzy lidene)amino)vinyl)imino)methyl) benzoic acid (SA3). Yield 44\%; mp. $254^{\circ} 256{ }^{\circ} \mathrm{C}$; FT-IR, $\mathrm{cm}^{-1}$ (rel. intensity), 3008 (s), 2241 (s), 1691 (s), 1665 (s), 1583 (m), 1411 (s), 1186 (s), 1051 (m), 872 (w), 782 (w). ${ }^{1} \mathrm{H}-\mathrm{NMR}$ $\left(\mathrm{CDCl}_{3}, 400 \mathrm{MHz}\right): \delta 8.66(\mathrm{~s}, 1 \mathrm{H}, \mathrm{CH}), 8.65(\mathrm{~s}, 1 \mathrm{H} . \mathrm{CH})$, 8.09 (d, $J=9.0 \mathrm{~Hz}, 2 \mathrm{H}, \mathrm{Ar}-\mathrm{H}), 7.70(\mathrm{~d}, J=9.0 \mathrm{~Hz}, 2 \mathrm{H}$, Ar-H), 6.78-6.67 (m, 3H, H-Ar), 3.82 (s, 6H, CH). ${ }^{13} \mathrm{C}-$ NMR (CDCl3, $100 \mathrm{MHz}): \delta 168.95,162.18,147.11$, $146.77,139.90,136.73,136.40,135.66,129.61,127.12$, $115.28,106.57,102.25$, 56.04. Anal. Calcd. For $\mathrm{C}_{21} \mathrm{H}_{16} \mathrm{~N}_{4} \mathrm{O}_{4}: \mathrm{C}, 64.94 ; \mathrm{H}, 4.15 ; \mathrm{N}, 14.43$. Found: C, 65.02; H, 4.12; N, 14.39. EI-MS: $m / z 388$.

The general one-pot dyes reaction scheme is given in Fig. 1. Schiff base reaction process was used to prepare three dyes for DSSC devices by using different aromatic compounds. The aldehyde derivatives $(1,2$, and 3 in Fig. 1) were used as a donor part, DAMN as a $\pi$-bridge, and benzoic acid as an acceptor part. Different conditions were used to obtain maximum yields for these reactions, and Table 1 shows the summary of these reactions with different conditions. In these conditions were used a different equivalents addition of starting materials with different types of solvent to get the best yield. In all conditions, the donor was added firstly to react with the DAMN compound for $5 \mathrm{~h}$ and after that, the acceptor was added to the mixture to react with the resulted compound (got from the reaction of donor and DAMN) for $15 \mathrm{~h}$. Seven conditions were used to prepare SA1 compound and the best condition (number 5) was applied to the donor 2 and 3 to prepare compound SA2 and SA3 respectively. The same equivalents of the donor, $\pi$-bridge, and acceptor were used in condition number 1 and the yield was $18 \%$. In condition number 2 , the yield of reaction decreases (15\%) because the equivalent of the donor was more than the equivalent of acceptor and that led to the effect of the substitution of acceptor in the DAMN compound. The same reason affected the percentage yield in condition number 3 . The yields of reactions increased in conditions 4 and 5 and because the equivalent of the donor decreased, and the equivalents of acceptor and DAMN increased. 


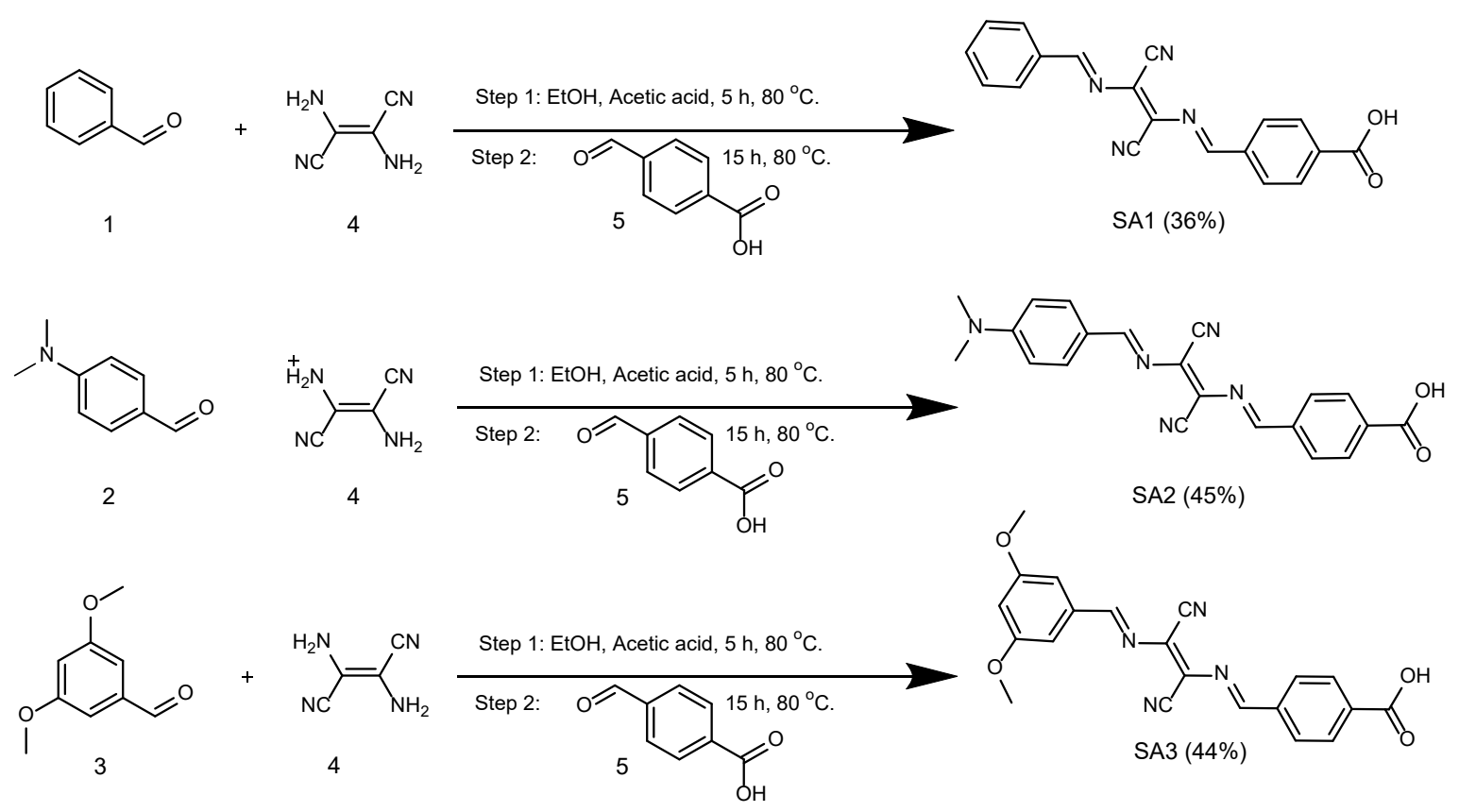

Fig 1. The synthesis scheme of SA1, SA2, and SA3 dyes

Table 1. The conditions of one-pot reaction in different equivalent (eq), solvent, and time

\begin{tabular}{ccccccc}
\hline Conditions & Donor (eq) & DAMN] (eq) & Acceptor (eq) & Solvent & Time (h) & Yield (\%) \\
\hline 1 & $1.0(1)$ & 1.0 & 1.0 & EtOH & 20 & 18 \\
2 & $1.5(1)$ & 1.0 & 1.0 & EtOH & 20 & 15 \\
3 & $1.5(1)$ & 1.0 & 1.5 & EtOH & 20 & 15 \\
4 & $1.0(1)$ & 1.5 & 1.5 & EtOH & 20 & 30 \\
5 & $1.0(1)$ & 1.5 & 2.0 & EtOH & 20 & 36 \\
6 & $1.0(1)$ & 1.5 & 2.0 & DMF & 20 & 28 \\
7 & $1.0(1)$ & 1.5 & 2.0 & THF & 20 & 18 \\
8 & $1.0(2)$ & 1.5 & 2.0 & EtOH & 20 & 45 \\
9 & $1.0(3)$ & 1.5 & 2.0 & EtOH & 20 & 44 \\
\hline
\end{tabular}

The solvent of the best condition (number 5) was changed by using DMF in condition number 6 and THF in condition number 7 but the yields were decreased to $28 \%$ and $18 \%$ respectively and that is could be due to the solubility effect of the starting materials.

The best yields in these conditions were given around $36 \%, 45 \%$, and $44 \%$ as a product for compounds SA1, SA2, and SA3 respectively. The best yield was achieved by reacting 1 mole of donor with $1.5 \mathrm{~mol}$ of DAMN for $5 \mathrm{~h}$ then added $2 \mathrm{~mol}$ of acceptor to the continuous reaction to get the final product. In general, the low yield of the resulted compounds could be due to the side products of the reaction (Fig. 2) which was come from disubstitutions of DAMN with a donor (compound
7) and disubstitutions of DAMN with acceptor (compound 8) and the yield of the side products was around $\sim 55 \%$ for both.

\section{FT-IR Spectroscopy}

The FTIR spectra of three dyes indicate a strong broad band for carboxylic acid at $\sim 3400 \mathrm{~cm}^{-1}$ for $\mathrm{OH}$ stretching and a strong sharp band at $\sim 1700 \mathrm{~cm}^{-1}$ for $\mathrm{C}=\mathrm{O}$ stretching. One strong band was observed in the three dyes within $\sim 2250 \mathrm{~cm}^{-1}$ due to the nitrile group of DAMN. A medium two bands were absorbed in $\sim 1630$ and $\sim 1410 \mathrm{~cm}^{-1}$ for $\mathrm{C}=\mathrm{N}$ stretching and $\mathrm{C}-\mathrm{N}$ stretching respectively for Schiff base reaction. Many weak to medium bands were observed between 990 and $650 \mathrm{~cm}^{-1}$ 
<smiles>N#C/C(N=Cc1ccccc1)=C(\C#N)N=Cc1ccccc1</smiles>

(7)<smiles>N#C/C(N=Cc1ccc(C(=O)O)cc1)=C(/C#N)N=Cc1ccc(C(=O)O)cc1</smiles>

(8)

Fig 2. The chemical structure of two side product compounds for the first reaction

due to in-plane and out-of-plane of $\mathrm{C}-\mathrm{H}$ vibration for benzene ring. A medium intensity band was observed at $1291 \mathrm{~cm}^{-1}$ due to $\mathrm{C}-\mathrm{N}$ stretching $\left(\mathrm{N}-\mathrm{CH}_{3}\right)$ for SA2 compound and a strong band was observed at $1186 \mathrm{~cm}^{-1}$ due to stretching of O-ether bond for SA3 compound.

\section{Proton NMR Spectroscopy}

The proton NMR $\left(\mathrm{CDCl}_{3}\right)$ of the first dye (SA1) shows two singlet peaks at $\delta 8.65$ and 8.63 for two protons of two imines groups, which resulted from the Schiff base reaction. Two doublets peak were investigated at $\delta 8.02$ and 7.70, also multiples peak from $\delta 7.60$ to 7.39 for $\mathrm{C}-\mathrm{H}$ proton of two benzene rings. The second dye (SA2) indicates singlet peaks at $\delta 8.68$ and 8.44 for two $\mathrm{C}-\mathrm{H}$ groups. Four doublet peaks as $\delta 8.06,7.64,7.39$, and 6.96 due to 8 protons in two benzene rings. Singlet peak shows at $\delta 2.93$ for 6 protons of the dimethylamine group. The last dye (SA3) shows two singlet peaks at $\delta 8.66$ and 8.65 for two $\mathrm{C}-\mathrm{H}$ groups and two doublet peaks for four protons appear at $\delta 8.09$ and 7.70 with multiples peak between 6.78 and 6.67 for two benzene rings. One singlet peak was investigated at $\delta 3.82$ for 6 protons of two ether groups (See supplementary information data).

\section{UV-Vis Spectroscopy}

The UV-Vis spectroscopy of three dyes (Fig. 3) was carried out in acetonitrile as a solvent. The three dyes SA1, SA2, and SA3 show a strong absorption band in the visible region with $\lambda_{\max }$ at 398,440 , and $442 \mathrm{~nm}$ respectively as well as good molar absorptivity ranging from $1.61 \times 10^{4}$ to $1.76 \times 10^{4} \mathrm{M}^{-1} \mathrm{~cm}^{-1}$ and this is possibly due to $\pi-\pi^{*}$ transition within conjugated between benzene rings in a day. The absorption band showed the redshift direction on going from SA1 to SA2 and SA3. Finally, the optical the

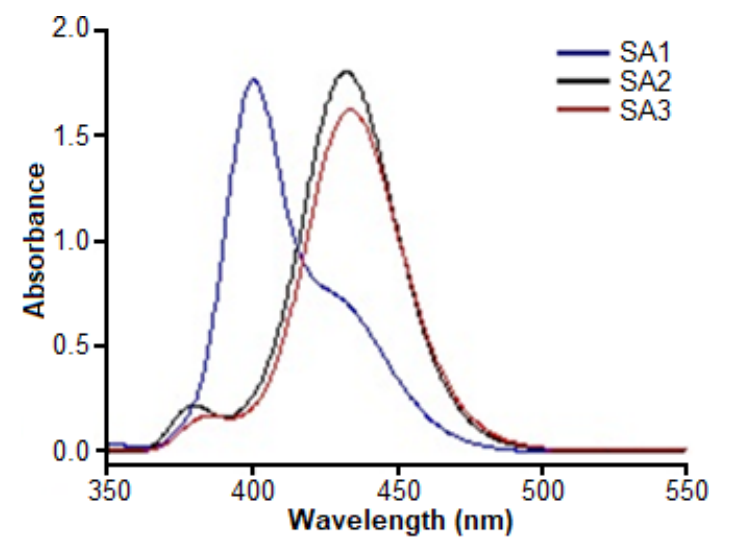

Fig 3. Absorption spectra of the three dyes SA1, SA2, and SA3 $\left(1 \times 10^{-4} \mathrm{M}\right)$

band gap $\left(\mathrm{E}_{\mathrm{opt}}\right)$ of the dyes SA1, SA2, and SA3 were 2.88, 2.53 , and $2.50 \mathrm{eV}$ respectively.

\section{Theoretical Calculation}

The geometry and electronic properties of the three dyes were investigated theoretically by using density functional theory (DFT) performed by using Gaussian 09 software. All dyes calculations were tested under vacuum by using Lee-Yang-Parr's gradient corrected correlation (B3LYP) functional and 6-311G $(d, p)$ basis set [38-39].

The molecular orbital and geometry for three dyes showed in Fig. 4. For compound SA1 and SA2, the HOMO orbital is delocalized throughout the benzene ring and dimethylaniline, respectively as well as on the DAMN part. The LUMO for the same dyes is delocalized over the DAMN and benzoic acid (acceptor part). This mixing in electron distribution between donor and acceptor part negatively affects the charge separation in the dye and that led to the effect of dye efficiency in the solar cell. On the other hand, the HOMO orbital 


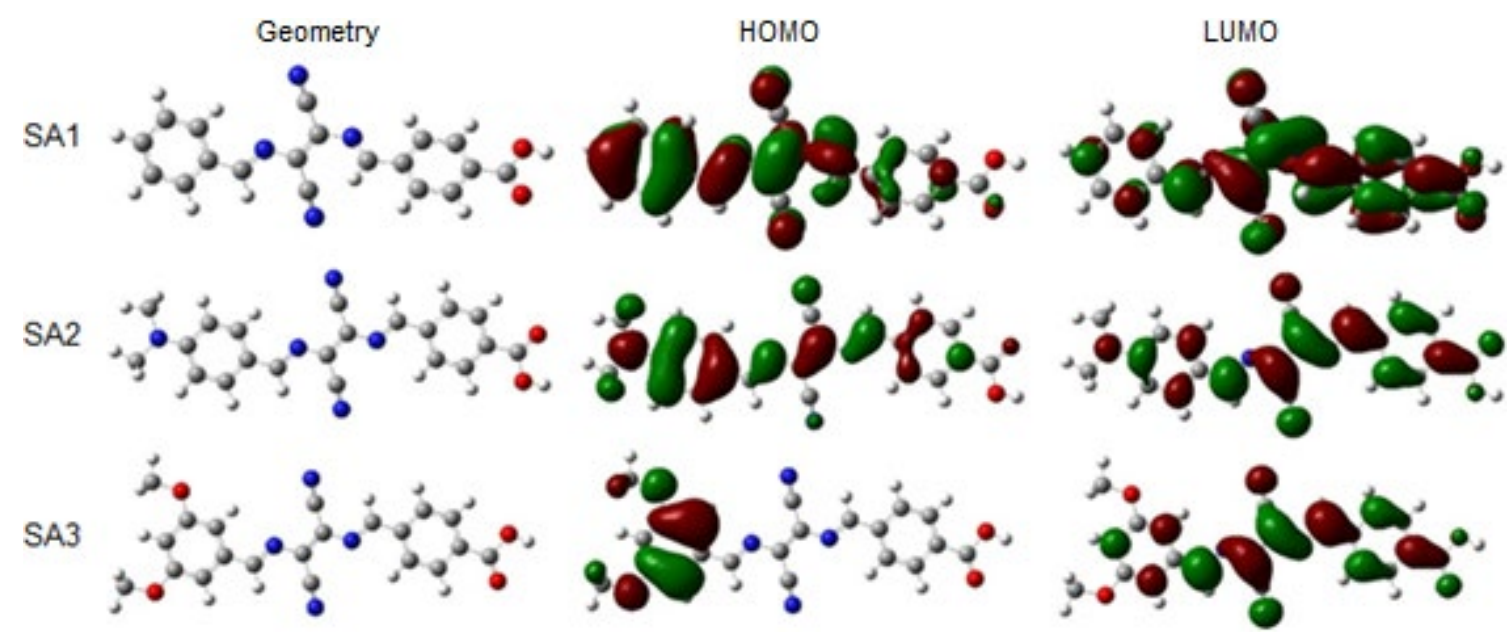

Fig 4. The geometry and frontier molecular orbital of three dyes (SA1, SA2, and SA3) calculated by DFT

in dye SA3 is delocalized over dimethoxybenzene and the LUMO is delocalized throughout the DAMN and benzoic acid which made charge separation in the dye. The optimization geometry of the three dyes was shown a planer shape with the substitution in dimethylamine for compound SA2 and dimethoxy in compound SA3 laying out-of-plane to avoid dye aggregation which improved the solubility. The computed energy gap for the SA1, SA2, and SA3 were $2.56,2.50$, and $2.51 \mathrm{eV}$ respectively and these results are similar to the $\mathrm{E}_{\mathrm{opt}}$ results.

\section{Device Testing}

The three sensitizers were tested as a dye in DSSCs by using iodide/triiodide as electrolyte solution between two electrodes and the devices were tested at AM 1.5 $\left(100 \mathrm{~mW} \mathrm{~cm}^{-2}\right)$. Power conversion efficiency (PCE) of dyes was measured by open-circuit voltage $\left(\mathrm{V}_{\mathrm{oc}}\right)$, short circuit current $\left(\mathrm{J}_{\mathrm{sc}}\right)$, and fill factor $(\mathrm{FF})$ and all the results are shown in Table 2. There is a big difference in I-V curve data between SA3 and other dyes (see supplementary information). The $\mathrm{J}_{\mathrm{sc}}$ value of compound SA3 is $1.21 \mathrm{~mA} / \mathrm{cm}^{2}$ and for SA1 and SA2 are $0.15,0.77$ respectively, indicating that the charge mobility of SA3 dye is more efficient than other dyes [40]. The I-V curve data show that the best efficiency was recorded with SA3 dye $(0.38 \%)$ then with SA2 $(0.22 \%)$ and finally with SA1 $(0.09 \%)$. The low efficiency of the three dyes was may be due to the mixing of electron distribution donor and accepter in DAMN part and that affected the charge separation between two parts.

\section{- CONCLUSION}

In conclusion, three novel dyes containing a DAMN as a $\pi$-bridge spacer were synthesized in a onepot reaction. The design of the dyes has given us to investigate the ability of the DAMN compound as a $\pi$ conjugated spacer on DSSCs performance. The reaction conditions were optimized to get the highest yield. All dyes were characterized by different techniques such as FT-IR, ${ }^{1} \mathrm{H}-\mathrm{NMR}$, elemental microanalysis, mass spectroscopy, and UV-Vis. The computational studies of these dyes showed a mixing in electron distribution between donor and acceptor in $\pi$-bridge part (DAMN) which affected the efficiency of dyes in DSSC devises and the three dyes were indicated a poor efficiency in DSSC.

Table 2. I-V data for SA1, SA2, and SA3 dyes with N719 as a control

\begin{tabular}{cccccc}
\hline Dyes & $\mathrm{J}_{\mathrm{sc}}\left(\mathrm{mA} / \mathrm{cm}^{2}\right)$ & $\mathrm{V}_{\mathrm{oc}}(\mathrm{V})$ & $\mathrm{FF}$ & PCE (\%) & PCE avg. (\%) \\
\hline SA1 & 0.15 & 0.82 & 35.6 & 0.09 & 0.07 \\
$\mathrm{SA} 2$ & 0.77 & 0.82 & 36.1 & 0.22 & 0.19 \\
$\mathrm{SA} 3$ & 1.21 & 0.91 & 37.9 & 0.38 & 0.34 \\
N719 & 10.2 & 0.76 & 64.2 & 5.40 & 5.38 \\
\hline
\end{tabular}




\section{- ACKNOWLEDGMENTS}

This work was supported by Al-Karkh University of science and Al-Nahrain University, Baghdad, Iraq.

\section{- REFERENCES}

[1] Singh, G.K., 2013, Solar power generation by PV (photovoltaic) technology: A review, Energy, 53, 1-13.

[2] Gong, J., Sumathy, K., Qiao, Q., and Zhou, Z., 2017, Review on dye-sensitized solar cells (DSSCs): Advanced techniques and research trends, Renewable Sustainable Energy Rev., 68, 234-246.

[3] Malinowski, M., Leon, J.I., and Abu-Rub, H., 2017, Solar photovoltaic and thermal energy systems: Current technology and future trends, Proc. IEEE, 105 (11), 2132-2146.

[4] Abdalhadi, S.M., Connell, A., Zhang, X., Wiles, A.A., Davies, M.L., Holliman, P.J., and Cooke, G., 2016, Convenient synthesis of EDOT-based dyes by $\mathrm{CH}$ activation and their application as dyes in dyesensitized solar cells, J. Mater. Chem. A, 4 (40), 15655-15661.

[5] Shalini, S., Balasundaraprabhu, R., Kumar, T.S., Prabavathy, N., Senthilarasu, S., and Prasanna, S., 2016, Status and outlook of sensitizers/dyes used in dye sensitized solar cells (DSSC): A review, Int. J. Energy Res., 40 (10), 1303-1320.

[6] Prabavathy, N., Shalini, S., Balasundaraprabhu, R., Velauthapillai, D., Prasanna, S., and Muthukumarasamy, N., 2017, Enhancement in the photostability of natural dyes for dye-sensitized solar cell (DSSC) applications: A review, Int. J. Energy Res., 41 (10), 1372-1396.

[7] Sugathan, V., John, E., and Sudhakar, K., 2015, Recent improvements in dye sensitized solar cells: A review, Renewable Sustainable Energy Rev., 52, 54-64.

[8] Ahmad, M.S., Pandey, A.K., and Abd Rahim, N., 2017, Advancements in the development of $\mathrm{TiO}_{2}$ photoanodes and its fabrication methods for dye sensitized solar cell (DSSC) applications. A review, Renewable Sustainable Energy Rev., 77, 89-108.

[9] Mozaffari, S., Nateghi, M.R., and Zarandi, M.B., 2017, An overview of the challenges in the commercialization of dye sensitized solar cells, Renewable Sustainable Energy Rev., 71, 675-86.

[10] Urbani, M., Grätzel, M., Nazeeruddin, M.K., and Torres, T., 2014, Meso-substituted porphyrins for dye-sensitized solar cells, Chem. Rev., 114 (24), 12330-12396.

[11] Obotowo, I.N., Obot, I.B., and Ekpe, U.J., 2016, Organic sensitizers for dye-sensitized solar cell (DSSC): Properties from computation, progress and future perspectives, J. Mol. Struct., 1122, 80-87.

[12] Carella, A., Borbone, F., and Centore, R., 2018, Research progress on photosensitizers for DSSC, Front. Chem., 6, 113-127.

[13] Ludin, N.A., Al-Alwani Mahmoud, A.M., Mohamad, A.B., Kadhum, A.A.H., Sopian, K., and Abdul Karim, N.S., 2014, Review on the development of natural dye photosensitizer for dyesensitized solar cells, Renewable Sustainable Energy Rev., 31, 386-396.

[14] O'Regan, B., and Grätzel, M., 1991, A low-cost, high-efficiency solar cell based on dye-sensitized colloidal $\mathrm{TiO}_{2}$ films, Nature, 353 (6346), 737-740.

[15] Nazeeruddin, M.K., Péchy, P., Renouard, T., Zakeeruddin, S.M., Humphry-Baker, R., Comte, P., Liska, P., Cevey, L., Costa, E., Shklover, V., Spiccia, L., Deacon, G.B., Bignozzi, C.A., and Grätzel, M., 2001, Engineering of efficient panchromatic sensitizers for nanocrystalline $\mathrm{TiO}_{2}$-based solar cells, J. Am. Chem. Soc., 123 (8), 1613-1624.

[16] Kim, B.G., Zhen, C.G., Jeong, E.J., Kieffer, J., and Kim, J., 2012, Organic dye design tools for efficient photocurrent generation in dye-sensitized solar cells: Exciton binding energy and electron acceptors, Adv. Funct. Mater., 22 (8), 1606-1612.

[17] Choi, H., Baik, C., Kang, S.O., Ko, J., Kang, M.S., Nazeeruddin, M.K., and Grätzel, M., 2008, Highly efficient and thermally stable organic sensitizers for solvent-free dye-sensitized solar cells, Angew. Chem. Int. Ed., 47 (2), 327-330.

[18] Lin, R.Y.Y., Wu, F.L., Li, C.T., Chen, P.Y., Ho, K.C., and Lin, J.T., 2015, High-performance aqueous/organic dye-sensitized solar cells based on 
sensitizers containing triethylene oxide methyl ether, ChemSusChem, 8 (15), 2503-2513.

[19] Hara, K., Sato, T., Katoh, R., Furube, A., Ohga, Y., Shinpo, A., Suga, S., Sayama, K., Sugihara, H., and Arakawa, H., 2003, Molecular design of coumarin dyes for efficient dye-sensitized solar cells, J. Phys. Chem. B, 107 (2), 597-606.

[20] Jiao, Y., Zhang, F., Grätzel, M., and Meng, S., 2013, Structure-property relations in all-organic dyesensitized solar cells, Adv. Funct. Mater., 23 (4), 424429.

[21] Mishra, A., Fischer, M.K.R., and Bäuerle, P., 2009, Metal-free organic dyes for dye-sensitized solar cells: From structure: Property relationships to design rules, Angew. Chem. Int. Ed., 48 (14), 2474-2499.

[22] El-Meligy, A.B., Koga, N., Iuchi, S., Yoshida, K., Hirao, K., Mangood, A.H., and El-Nahas, A.M., 2018, DFT/TD-DFT calculations of the electronic and optical properties of bis- $N, N$-dimethylaniline-based dyes for use in dye-sensitized solar cells, J. Photochem. Photobiol., A, 367, 332-346.

[23] Naik, P., Su, R., Babu, D.D., El-Shafei, A., and Adhikari, A.V., 2017, Structurally simple D-A-type organic sensitizers for dye-sensitized solar cells: Effect of anchoring moieties on the cell performance, J. Iran. Chem. Soc., 14 (11), 2457-2466.

[24] Hara, K., Sato, T., Katoh, R., Furube, A., Yoshihara, T., Murai, M., Kurashige, M., Ito, S., Shinpo, A., Suga, S., and Arakawa, H., 2005, Novel conjugated organic dyes for efficient dye-sensitized solar cells, $A d v$. Funct. Mater., 15 (2), 246-252.

[25] Sánchez-de-Armas, R., San Miguel, M.Á., Oviedo, J., and Sanz, J.F., 2012, Coumarin derivatives for dye sensitized solar cells: A TD-DFT study, Phys. Chem. Chem. Phys., 14 (1), 225-233.

[26] Wang, Z.S., Cui, Y., Hara, K., Dan-oh, Y., Kasada, C., and Shinpo, A., 2007, A high-light-harvestingefficiency coumarin dye for stable dye-sensitized solar cells, Adv. Mater., 19 (8), 1138-1141.

[27] Wang, Z.S., Cui, Y., Dan-oh, Y., Kasada, C., Shinpo, A., and Hara, K., 2007, Thiophene-functionalized coumarin dye for efficient dye-sensitized solar cells: Electron lifetime improved by coadsorption of deoxycholic acid, J. Phys. Chem. C, 111 (19), 72247230.

[28] Cariello, M., Abdalhadi, S.M., Yadav, P., Decoppet, J.D., Zakeeruddin, S.M., Grätzel, M., Hagfeldt, A., and Cooke, G., 2018, An investigation of the roles furan versus thiophene $\pi$-bridges play in donor- $\pi$ acceptor porphyrin based DSSCs, Dalton Trans., 47 (18), 6549-6556.

[29] Gao, P., Tsao, H.N., Yi, C., Grätzel, M., and Nazeeruddin, M.K., 2014, Extended $\pi$-bridge in organic dye-sensitized solar cells: The longer, the better?, Adv. Energy Mater., 4 (7), 1301485.

[30] Tsuzuki, K., and Tada, M., 1986, The syntheses of pteridin-2-one derivatives from diaminomaleonitrile (DAMN), J. Heterocycl. Chem., 23 (5), 1299-1301.

[31] Zhou, H., Wang, J., Chen, Y., Xi, W., Zheng, Z., Xu, D., Cao, Y., Liu, G., Zu, W., Wu, J., and Tian, Y., 2013, New diaminomaleonitrile derivatives containing aza-crown ether: Selective, sensitive and colorimetric chemosensors for $\mathrm{Cu}(\mathrm{II})$, Dyes Pigm., 98 (1), 1-10.

[32] Anitha, C., Sheela, C.D., Tharmaraj, P., and Shanmugakala, R., 2013, Studies on synthesis and spectral characterization of some transition metal complexes of azo-azomethine derivative of diaminomaleonitrile, Int. J. Inorg. Chem., 2013, 436275.

[33] Aruna, A., Rani, B., Swami, S., Agarwala, A., Behera, D., and Shrivastava, R., 2019, Recent progress in development of 2,3-diaminomaleonitrile (DAMN) based chemosensors for sensing of ionic and reactive oxygen species, $R S C A d v$., 9 (52), 3059930614.

[34] Li, Z., Liu, C., Wang, J., Wang, S., Xiao, L., and Jing, X., 2019, A selective diaminomaleonitrile-based dual channel emissive probe for $\mathrm{Al}^{3+}$ and its application in living cell imaging, Spectrochim. Acta, Part A, 212, 349-355.

[35] Fuse, S., Sugiyama, S., Maitani, M.M., Wada, Y., Ogomi, Y., Hayase, S., Katoh, R., Kaiho, T., and Takahashi, T., 2014, Elucidating the structureproperty relationships of donor- $\pi$-acceptor dyes 
for dye-sensitized solar cells (DSSCs) through rapid library synthesis by a one-pot procedure, Chem. Eur. J., 20 (34), 10685-10694.

[36] Matsumura, K., Yoshizaki, S., Maitani, M.M., Wada, Y., Ogomi, Y., Hayase, S., Kaiho, T., Fuse, S., Tanaka, H., and Takahashi, T., 2015, Rapid synthesis of thiophene-based, organic dyes for dye-sensitized solar cells (DSSCs) by a one-pot, four-component coupling approach, Chem. Eur. J., 21 (27), 97429747.

[37] Irie, S., Fuse, S., Maitani, M.M., Wada, Y., Ogomi, Y., Hayase, S., Kaiho, T., Masui, H., Tanaka, H., and Takahashi, T., 2016, Rapid synthesis of D-A'- $\pi-A$ dyes through a one-pot three-component SuzukiMiyaura coupling and an evaluation of their photovoltaic properties for use in dye-sensitized solar cells, Chem. Eur. J., 22 (7), 2507-2514.

[38] Lee, C., Yang, W., and Parr, R.G., 1988, Development of the Colle-Salvetti correlationenergy formula into a functional of the electron density, Phys. Rev. B: Condens. Matter, 37 (2), 785789.

[39] Becke, A.D., 1993, Density-functional thermochemistry. III. The role of exact exchange, $J$. Chem. Phys., 98 (7), 5648-5652.

[40] Qu, S., Wang, B., Guo, F., Li, J., Wu, W., Kong, C., Long, Y., and Hua, J., 2012, New diketo-pyrrolopyrrole (DPP) sensitizer containing a furan moiety for efficient and stable dye-sensitized solar cells, Dyes Pigm., 92 (3), 1384-1393. 